\title{
Graduates' personality characteristics and labor market entry an empirical study among dutch economics graduates
}

Citation for published version (APA):

Semeijn, J. H., Boone, C. A. J. J., van der Velden, R. K. W., \& van Witteloostuijn, A. (2005). Graduates' personality characteristics and labor market entry an empirical study among dutch economics graduates. Economics of Education Review, 24(1), 67-83. https://doi.org/10.1016/j.econedurev.2004.03.006

Document status and date:

Published: 01/01/2005

DOI:

10.1016/j.econedurev.2004.03.006

Document Version:

Publisher's PDF, also known as Version of record

Please check the document version of this publication:

- A submitted manuscript is the version of the article upon submission and before peer-review. There can be important differences between the submitted version and the official published version of record.

People interested in the research are advised to contact the author for the final version of the publication, or visit the DOI to the publisher's website.

- The final author version and the galley proof are versions of the publication after peer review.

- The final published version features the final layout of the paper including the volume, issue and page numbers.

Link to publication

\footnotetext{
General rights rights.

- You may freely distribute the URL identifying the publication in the public portal. please follow below link for the End User Agreement:

www.umlib.nl/taverne-license

Take down policy

If you believe that this document breaches copyright please contact us at:

repository@maastrichtuniversity.nl

providing details and we will investigate your claim.
}

Copyright and moral rights for the publications made accessible in the public portal are retained by the authors and/or other copyright owners and it is a condition of accessing publications that users recognise and abide by the legal requirements associated with these

- Users may download and print one copy of any publication from the public portal for the purpose of private study or research.

- You may not further distribute the material or use it for any profit-making activity or commercial gain

If the publication is distributed under the terms of Article $25 \mathrm{fa}$ of the Dutch Copyright Act, indicated by the "Taverne" license above, 


\title{
Graduates' personality characteristics and labor market entry an empirical study among dutch economics graduates
}

\author{
Judith Semeijn ${ }^{\mathrm{a}, *}$, Christophe Boone ${ }^{\mathrm{b}}$, Rolf van der Velden ${ }^{\mathrm{a}}$, \\ Arjen van Witteloostuijn ${ }^{\mathrm{c}}$ \\ ${ }^{a}$ Research Centre for Education and the Labour Market, Maastricht University, P.O. Box 616, 6200 MD Maastricht, The Netherlands \\ ${ }^{\mathrm{b}}$ Faculty of Applied Economics, University of Antwerpen, Prinsstraat 13, 2000 Antwerpen, Belgium \\ ${ }^{\mathrm{c}}$ Faculty of Economics, Department of International Economics and Business, University of Groningen, P. O. Box 800, \\ 9700 A V Groningen, The Netherlands
}

Received 2 September 2002; accepted 18 March 2004

\begin{abstract}
In this study, we explore the value of personality characteristics in explaining success in labor market entry with a sample of graduates in economics from Maastricht University (the Netherlands). Specifically, the paper addresses the following twofold research question: does personality explain labor market outcomes, and how much weight does this 'generic' factor have compared to traditional human capital and individual preference variables such as study results, study field and demographic characteristics? Personality is measured both by separate indicators for traits as well as by the so-called 'profiles', based on combinations of these indicators. The results show that both measurement methods reveal significant personality effects, which are independent from the effects of traditional human capital variables, such as grade point averages in the academic program, and work experience. A key finding is that both types of factors have their own and independent effect on labor market outcomes.
\end{abstract}

(C) 2004 Elsevier Ltd. All rights reserved.

JEL classification: $\mathrm{j} 24$

Keywords: Human capital; Personality; Productivity

\section{Introduction}

Due to rapid technological developments and the expanding international orientation of many organizations, labor market demands have changed. Working environments require people to be more flexible in order to keep up with the continuous changes and developments inside and outside the organization. This is

\footnotetext{
${ }^{*}$ Corresponding author. Tel.: + 31-43-3883647; fax: +31-433884914.

E-mail address: jh.semeijn@roa.unimaas.nl (J. Semeijn).
}

reflected in personnel selection practices, where more and more emphasis is put on the so-called 'soft' factors and 'generic' competencies such as communication skills and personality features (Spencer \& Spencer, 1993). Work settings are less structured and productivity is more dependent on individuals' contributions through, e.g., interpersonal communication and teamwork. This dependency requires different skills and competences from people, which are not automatically acquired in the traditional educational context (Boyatzis et al., 1995). These new key qualifications are also called generic competences (Nijhof, 1998). Examples of these generic 
requirements and the importance of personality features for job selection can be found in many job advertisements in magazines and papers. Catchy lines like 'a solid personality required', 'independence and flexibility are requirements' and 'we are looking for an ambitious, enthusiastic personality' are part of the job ads, time and again.

Notwithstanding these observations, the importance of these new generic requirements for the labor market have only recently been recognized as such, and have not yet (fully) been integrated into the research models and explanations for labor market performance. In so far as personality received attention in the context of workrelated issues, most studies have been conducted in the field of organizational research. In this latter research domain, mainly the relationship between employee personality and job performance has been studied. To date, as far as we know, not much systematic researchif any-has been conducted into the relationship between personality features on the one hand, and labor market entry and early career success on the other hand. It is here where the current paper hopes to offer a contribution. That is, the purpose of this paper is to analyze the importance of personality features for early labor market performance, next to and on top of more specific kinds of competences, characterized by traditional human capital variables such as the grade point averages (GPAs) in the academic program followed, working experience and study field. So, this paper will address the following twofold research question: to what extent does personality predict labor market outcomes of graduates in economics, and how much weight does this effect have compared to traditional human capital variables such as study results and study field? Additionally, we discuss the possible theoretical explanations for the effects of graduates' personality on labor market outcomes.

The paper is organized as follows. In Section 2, the theoretical background of this study will be reviewed, and the (course-grained) hypothesis for this paper will be presented. In Section 3, the issue of the measurement of personality (profiles and traits) will be addressed by discussing the specific personality constructs used in the current study in more detail. In Section 4, the econometric methodology for analyzing the effect of personality features on labor market outcomes will be introduced. In Section 5, the key results of the analyses will be presented. Finally, in Section 6, the main conclusions will be summarized, and considerations for future research will be given.

\section{Theoretical background}

In the 1990s, a number of large meta-analytic reviews into the value of personality measures revealed accep- table and promising results in explaining and predicting work-related outcomes (e.g., Barrick \& Mount, 1991; Tett, Jackson, \& Rothstein, 1991). These findings, in fact, reflect the growing importance of personality measures for job selection at that time, which triggered a renewed interest in using personality constructs for research in the context of work. Nicholson (1996) mainly discusses the relevance of personality research for organizational settings in terms of person-environment fit (matching), personal change and employee development. Although issues of personality have gained serious attention in organizational research, the effects of personality features on (early) labor market outcomes for those who enter the labor market for the first time have been poorly addressed. There are a few studies into the effects of personality (i.e., psychological human capital) on wages (e.g., Duncan \& Dunifon, 1998; Filer, 1981; Goldsmith, Veum, \& Darity, 1997; Murnane, Willett, Braatz, \& Duhaldeborde, 2001). However, other labor market outcomes have barely been considered at all, as yet. Since the importance of personality characteristics in personnel selection practices is evident, this type of research could fill an important gap in both the organizational (work) and labor market literatures.

Without any prior theoretical restrictions, given the lack of earlier work, we decided to merely explore the various possible relationships between personality features and labor market outcomes. For this purpose, an explorative conceptual research model will be formulated that captures the possible effects of personality characteristics on early individual labor market success. This model is summarized in Fig. 1.

For the sake of simplicity, standard control variables such as age and gender are left out in the research model (but not in the empirical analyses).

Filer (1981) already presented a comparable framework in the context of a test for the effects of 'affective' human capital, next to traditional variables, on wages. The 'human capital variables' construct in our scheme refers to traditional learning and educational outcome measures. On the one hand, as suggested in Fig. 1, personality features can have a direct effect on labor market outcomes, which is illustrated by Arrow 1. In this way, personality characteristics have their own independent effect on labor market success (or failure, for that matter), for example, because employers use

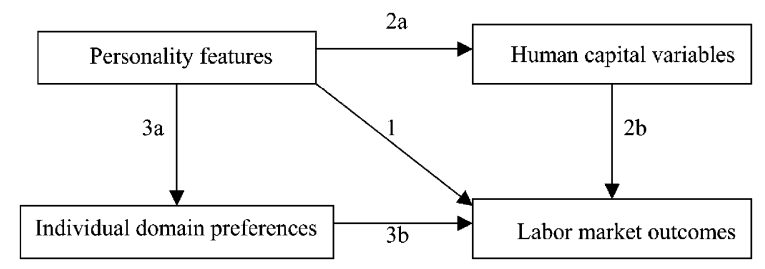

Fig. 1. An explorative conceptual research model. 
personality impressions and personality tests as direct screening devices in the selection of new employees (Smith \& George, 1994; Spencer \& Spencer, 1993). On the other hand, personality features could have an indirect effect on labor market outcomes. This indirect effect may come through two different routes.

First, personality characteristics are known to affect learning outcomes (Borg \& Shapiro, 1996; Timmers, 1997). In turn, educational achievements are considered to influence labor market outcomes, as extensively argued in traditional labor market research. This indirect relationship is illustrated by Arrow 2a-b. Human capital theory (Becker, 1964) indeed argues that the level and type of education are the main sources of productivity of people in the labor market. With respect to the impact of the human capital variables, another possible route for indirect personality effects is suggested by the screening theory in labor market research. This theory suggests that employees are selected on the basis of the level and type of education followed. That is, for employers, education is an ex ante indicator of the ex post 'trainability' of the potential employees, as well as of other "desired innate capabilities that enhances the capacity to become productive' (Thurow, 1975). After all, real productivity is to be ex post acquired on the job. In this context, the selection on the basis of educational outcomes might reflect the selection on 'innate capabilities' that may well refer to personality characteristics.

Second, personality features can have an indirect impact on labor market outcomes via associated differences in individual preferences as far as study fields, job characteristics and organization types are concerned. This route - indicated by Arrow 3a-b-is therefore not dealing with employer selection behavior, but rather with the choices made by potential employees. More specifically, Schneider (1987) argues that people are attracted to certain jobs (and organizations, for that matter) that fit their personality traits. When we follow this line of thought, the attraction can start with the choice of a certain field of study (or specialization track therein), to continue with attraction to certain jobs and/ or organizations. That is, personality features are associated with specific individual domain preferences in terms of, specifically, study fields, job characteristics and organization types.

Based on these theoretical considerations, we will test the following hypothesis:

Personality features have an effect on labor market outcomes, net of traditional human capital variables (e.g., study results) and individual domain preferences (e.g., study fields).

As said, given the lack of earlier work, we refrain from formulating specific hypotheses about the labor market effects of specific personality features. Rather, we let the data speak, which implies that the current study must be regarded as an explorative steppingstone for more indepth future work.

\section{Personality measurement}

Various definitions of personality float around in the literature (Pervin, 1990). They differ as to their underlying theoretical assumptions, as well as in terms of their usefulness in empirical work. We propose a working definition that reflects the use of the personality constructs in this study: personality is defined as a rather stable trait, or set of traits, of people that directs their behavior in different situations. A recent study concludes that personality displays modest continuity from childhood to adulthood, with the consistency in personality increasing with age (Caspi \& Roberts, 2001). Personality measures that are frequently used in empirical studies into the relationship between personality features and work characteristics are the so-called Big Five personality constructs (Tett et al., 1991). Factor-analytic research has revealed that these constructs (agreeableness, conscientiousness, emotional stability, extraversion and openness to experience) cover the broad domain of personality to a large extent (Barrick \& Mount, 1991; Robbins, 1996). However, other scholars argue that different, more specific personality constructs are useful as well, or even more useful, for work-related research because hypotheses with respect to work-related outcomes can be specified in greater detail when using specific personality constructs (Robertson, 1994). A number of specific personality constructs have gained substantial credibility in the area of work-related studies, prominent examples being 'locus of control' (Boone, De Brabander, \& Van Witteloostuijn, 1996), 'type A behavior' (Tett et al., 1991), 'sensation seeking' (Van den Berg, 1992), and 'self-monitoring' (Kilduff \& Krackhardt, 1994). These constructs are often mentioned in handbooks and textbooks of organizational behavior (e.g., Robbins, 1996), having a solid research history. They are associated with acceptable values of validity and reliability in work-related research. The above four specific personality constructs will be used in this study, too.

Locus of control refers to the individual's generalized belief in internal versus external control of reinforcements. The concept was first introduced by Rotter (1966) in his social learning theory. He distinguishes people who believe that events are uncontrollable and that achievements are merely based on luck or the influence of other people or institutions (externals) vis-avis people who believe that they can influence their environment and that achievements do depend to a large extent on their own efforts (internals). Research 
conducted with this concept in relation to job functioning has concentrated on several different features, such as job satisfaction, absenteeism, job involvement and turnover (Blau, 1987; Spector, 1982). Generally speaking, internals seem to perform better in their jobs. However, differences between different kinds of jobs should be taken into account: internals seem to do well in complex tasks and in jobs which require initiative and independence, whereas externals seem to be better performers in structured, routine tasks and in jobs which require compliance (Robbins, 1996). With respect to a prominent issue in labor economics, internality appears to have an indirect and positive effect (via selfesteem) on wages (Goldsmith et al., 1997).

Type A behavior pertains to a behavioral pattern characterized by being in a hurry and trying to achieve more in less time. People with type A behavior are associated with impatience, hostility, a high level of competitiveness and a constant feeling of time urgency. In fact, this behavioral pattern has been recognized to stimulate coronary heart disease prone behavior. Type A behavior measures are therefore used to screen people in the context of health research (Appels, 1985; Friedman \& Rosenman, 1974). More recent research has questioned the relationship between type A behavior and heart disease (Gleick, 1999). This research does not refute the type A personality, just the relationship with heart disease. Research conducted with this concept related to job functioning has revealed that type A's are fast workers, who emphasize quantity over quality and who tend to make poor decisions because they make them too fast. In managerial positions, these characteristics are rarely desirable to reach the top positions (Friedman \& Rosenman, 1974). However, great salespersons are often associated with type A behavior. So, the continuous urge for achieving more in less time seems useful in particular labor market segments. Situational and organizational preferences of type A's are found to be associated with high performance standards, and the need to display effort (Burke \& Deszka, 1982; Feather \& Volkmer, 1988).

Self-monitoring involves the ability of people to adapt their self-presentation to the requirements of the environment or situation. It is therefore related to a person's sensibility for what is considered appropriate or desirable expressive behavior in different situations. It involves the ability to control and alter this behavior (Snyder, 1974). People scoring high on this trait can alter their expressive behavior according to the social requirements, despite feeling quite differently inside. People scoring low on this trait do behave more according to their own inner state of mind so that their expressive behavior is more in line with their own feelings and thoughts, without bothering much about what would be appropriate in a social sense. High selfmonitoring could be very useful in jobs which are associated with different roles (e.g., managerial jobs) or which require public appearance (e.g., sales jobs). At a general level, it seems that self-monitoring can enhance an individual's chances to obtain career success in organizations (Kilduff \& Krackhardt, 1994). Research with respect to the effect of self-monitoring on managerial career success reveals that high self-monitors achieve more cross-company promotions than low scorers, and obtain more internal promotions when they stay with the same employer (Kilduff \& Day, 1994). Furthermore, high self-monitors appear to be more active in searching for information about potential employers than low selfmonitors (Snyder \& Copeland, 1989).

Sensation seeking relates to the motivation to experience sensation (Feij \& Van Zuilen, 1984; Zuckerman, 1979a, 1991). People scoring high on this trait are characterized by a continuous need to experience new and varied, arousal triggering, events. They therefore like unpredictable and risky situations, whereas people scoring low on this trait prefer more predictable and stable environments. High scorers have a high level of arousal tolerance, whilst low scorers are associated with low arousal tolerance. This difference seems to have a biological basis (Zuckerman, 1979a). Research with respect to this personality characteristic and job functioning has focused on job preference and job fit, but also on job performance and work satisfaction. Additionally, the relationship with the job search process has been studied empirically (Van den Berg, 1992). That is, sensation seeking has been related to the ease and speed of finding a job, indicating that high sensation seekers find a full-time job faster than low sensation seekers do (Cellini \& Lorenz, 1983). There are also signs that high sensation seeking is associated with success in higher management jobs (Franken, 1988).

This staccato review of earlier work reveals that the above four personality constructs have all been studied in different empirical settings and for answering different work-related research questions (Robbins, 1996). Research has produced linear relationships between these personality constructs and indicators of overall work performance, as well as with a series of more specific work-related outcomes. In practice, however, the importance of the personality of individuals is based on a particular combination of personality characteristics, summarized in the so-called profiles. In this profile context, the effects of the underlying traits may not be linear. The literature observes a need to deepen our understanding of the combined effect of different personality characteristics, and the shape of the relationship between personality factors and aspects of work behavior, to make further progress in unraveling the value of personality for work (Nicholson, 1996; Robertson, 1994). Until now, much research seems to merely analyze the effects of separate personality traits in the working context, even when using the Big Five 
personality instruments (e.g., Barrick \& Mount, 1993; Boudreau, Boswell, \& Judge, 2001; De Fruyt \& Mervielde, 1999). Therefore, in this paper's analyses, the above four personality traits will be used both separately and combined into the so-called personality profiles (as produced by cluster analysis).

\section{Data and methodology}

This study was conducted with a sample of economics graduates from Maastricht University in the Netherlands. This means that all of these graduates have Master's degrees. For 137 persons, we gathered measures of all four separate personality characteristics before their graduation in the period 1993-1995 in the context of skills and training courses that were then part of the study program (Boone, De Brabander, \& Van Witteloostuijn, 1999). To enlarge the sample, additional personality data have been collected after graduation for 200 graduates as well. In total, complete personality data are available for 308 Maastricht graduates. For 42 persons, personality measures are available twice or even three times. This group has been used to conduct testretest reliability analyses with respect to the personality constructs used here. For the purpose of this study, the personality data gathered during the study program are most valuable. For predicting labor market success during the entry phase, the personality data should be collected in advance to be sure that the direction of any association goes from personality features to labor market performance, rather than the other way around. Luckily, the results of the test-retest correlation analyses within our sample confirm the well-established assumption that personality characteristics are rather stable over time and over situations (e.g., Hogan, Hogan, \& Roberts, 1996). Therefore, to increase the sample size, we decided to supplement the sample of pre-graduation personality data with additional information gathered after graduation whenever pre-graduation personality measures were not available. As a second check, analyses with the four separate personality scales have been conducted for labor market outcomes while controlling for the effect of old and new cases by introducing dummy variables indicating old and new cases for all variables in the analysis. As no significant differences were found in the estimated effects of personality profiles or traits for old vis-a-vis new cases, only the results of the analyses with the complemented sample will be reported here.

Locus of control has been measured with a Dutch translation of the Rotter locus of control scale (Rotter, 1966). Whereas the original scale contains 29 forcedchoice items, the translated version has 37 items. The difference pertains to the amount of filler-items, which are included to obscure the purpose of the test. In the
Dutch translation, there are eight filler items more (producing a total of 14 filler items). We obtained a total locus of control score by counting the external alternatives chosen from the 23 forced-choice locus of control items (0-23). Thus, high scores imply an external orientation. An example of an item from the scale is the following: 'The things that happen to me are the consequence of my own behavior' (internal alternative) versus 'Sometimes I feel I have too little control over the direction in which my life develops'(external alternative). The reliability (Cronbach's alpha) and validity (test-retest correlation) of the Dutch translated version have been demonstrated with acceptable values in several studies (Boone, 1992; Boone, De Brabander, Gerits, \& Willeme, 1990; De Brabander, Boone, \& Gerits, 1992). In our sample, the reliability of the scale (Cronbach's alpha) is $0.74(n=325)$, which is rather satisfying. The test-retest correlation in our sub-sample is $0.61(n=42)$, which is acceptable, considering the large test-retest time span of about $2-3$ years. Normally, retesting takes place in about 2 weeks to 1 month (Goldsmith et al., 1997; Nicholson, 1996). Test-retest correlations reported by Rotter amount to 0.72 for elementary psychology students $(n=60)$ within a 1 month period, and to $0.55(n=117)$ in a 2 -month period (Rotter, 1966).

Type $A$ behavior has been measured by a Dutch adaptation of the original Jenkins Activity Survey (JAS) (Appels, 1985). The adapted version contains 24 forcedchoice items with some response categories being indicative of type A behavior, and others not. The indicative responses are valued with score 1 and the others with score 0 , implying a total score range that runs from 0 to 24. An example of a survey item is the following: 'Are you in a hurry when you have to go somewhere, even when you have enough time?' The Dutch JAS reveals satisfactory levels of reliability (Cronbach's alpha) and validity (Appels, 1985). In our sample, the reliability (Cronbach's alpha) is 0.76 $(n=329)$, and the test-retest correlation in our subsample is $0.65(n=42)$.

Self-monitoring has been measured with a Dutch translation of the 18-item self-monitoring scale (Snyder \& Gangestad, 1986). Respondents are asked to consider the 18 statements as true or false (forced choice), in their opinion. In fact, there are no true or false answers. The total score can be obtained by counting the number of high self-monitoring answers (in the 0-18 range). An example of a self-monitoring item is: 'I find it hard to copy the behavior of others'. The level of validity has been demonstrated to be sufficiently high (Snyder \& Gangestad, 1986). The reliability of the instrument in our sample (Cronbach's alpha) is $0.65 \quad(n=332)$. Test-retest correlation within our sub-sample is rather low $(0.57$, with $n=42)$, though. Taking into account the small number of cases in the sub-sample and the large 
Table 1

Results of cluster analyses with $2-5$ clusters for the personality constructs used

\begin{tabular}{|c|c|c|c|c|}
\hline & \multicolumn{4}{|c|}{ Explained variance $(\%)$ in personality scores for several cluster solutions } \\
\hline & Two-cluster solution & Three-cluster solution & Five-cluster solution & Five-cluster solution \\
\hline Type A behavior & 45.1 & 60.5 & 60.8 & 73 \\
\hline Locus of control & 32.5 & 52.3 & 59.6 & 58.7 \\
\hline Sensation seeking & 10.1 & 9.2 & 13.7 & 13.7 \\
\hline Self-monitoring & 7.5 & 9.5 & 30.1 & 34.1 \\
\hline \multirow[t]{4}{*}{ No. of clusters } & $1=139$ & $1=102$ & $1=63$ & $1=100$ \\
\hline & $2=169$ & $2=92$ & $2=80$ & $2=62$ \\
\hline & & $3=114$ & $3=81$ & $3=65$ \\
\hline & & & $4=84$ & $4=38$ \\
\hline No. of total sample & 308 & 308 & 308 & 308 \\
\hline
\end{tabular}

interval time, we decided nevertheless to consider this to be acceptable.

Sensation seeking has been measured with the socalled Excitement Need List ('Spanningsbehoeftelijst': SBL), developed by Feij and Van Zuilen (1984). This is a Dutch translation of the American Sensation Seeking Scale (Zuckerman, 1979b). The SBL consists of 51 sensation seeking items and 16 filler items, for which respondents have to indicate on a five-point scale to what extent they (dis)agree with the statements. An example of a statement is: 'Camping in a lonely area under primitive circumstances seems a great experience to me'. The composite total sensation seeking score is obtained by summing the scores for the individual items (in the 0-51 range). The reliability (Cronbach's alpha) and validity levels of the scale have been demonstrated to be satisfactory (Feij \& Van Zuilen, 1984). In our sample, the reliability level is very satisfactory, too, with a Cronbach's alpha of $0.84 \quad(n=323)$. Test-retest correlation within our sub-sample is high $0.82(n=41)$.

In combination with the available labor market data the sample size decreases from 308 to 171 graduates.

To check for possible biases in the personality scores of people for whom labor market data are available compared to those for whom no data are available, significance of differences in personality scores are estimated for the four constructs with analyses of variances. Only a significant higher score for sensation seeking is found for the group for whom labor market data are available. We must keep this finding in mind in the discussion of the results. In this context, recall that earlier research related (higher) sensation seeking (positively) to the ease and speed of finding a job.

In order to measure the effect of personality profiles on labor market outcomes, the available scores on the specific personality constructs in our study sample have been submitted to four $K$-means cluster analyses with $2-5$ clusters. The four or five-cluster solution reveals the best results with respect to explained variance in the scores on the four separate personality scales. In Table 1, they explained variance percentages are presented.

However, because of the small amount of cases remaining in the clusters in the five-cluster solution when conducting labor market analyses, we decided to opt for the four-cluster solution in the further analyses. Table 2 shows the descriptives of the four-cluster solution.

Based on the content meaning of the separate personality measures, the cluster (profile) scores can be interpreted as follows:

1. Profile 1 involves ambitious, external individuals, who do not particularly favor sensation seeking and who like to adapt their behavior according to the perceived (social) requirements of the environment.

2. Profile 2 relates to less ambitious, internal individuals, who have comparable scores on sensation seeking and self-monitoring as profile 1 individuals.

3. Profile 3 is associated with ambitious, internal individuals, who score comparable on sensation seeking as the profile 1 and 2 individuals, but who are less adaptive to the perceived (social) requirements of the environment.

4. Profile 4 pertains to unambitious, external individuals, who score the lowest on sensation seeking (for that matter) and who are the least adaptive to the perceived (social) requirements of the environment.

As a check, the cluster analysis has been conducted for the reduced personality sample group $(n=171)$, too. Comparable results appear for the content meaning of the then resulting clusters. The percentage of cases per cluster remains comparable as well. ${ }^{1}$

\footnotetext{
${ }^{1}$ As the $K$-means cluster analysis on the personality data of 171 graduates would only reveal less reliable results (the larger amount of personality data available in this explorative study is considered to be more representative for the types of profiles
} 
Table 2

Descriptives for personality traits in each cluster

\begin{tabular}{|c|c|c|c|c|c|c|c|c|}
\hline \multirow[t]{2}{*}{ Personality trait (score range) } & \multicolumn{2}{|c|}{ Profile 1} & \multicolumn{2}{|c|}{ Profile 2} & \multicolumn{2}{|c|}{ Profile 3} & \multicolumn{2}{|c|}{ Profile 4} \\
\hline & Mean & SD & Mean & SD & Mean & $\mathrm{SD}$ & Mean & $\mathrm{SD}$ \\
\hline Type A behavior (0-24) & 16.90 & 3.12 & 11.98 & 2.37 & 17.22 & 2.45 & 9.62 & 2.67 \\
\hline Locus of control (0-23) & 13.79 & 2.44 & 7.11 & 2.53 & 7.98 & 2.09 & 13.38 & 2.86 \\
\hline Sensation seeking $(0-51)$ & 12.53 & 1.49 & 13.00 & 1.49 & 12.77 & 1.58 & 11.42 & 1.75 \\
\hline \multirow[t]{2}{*}{ Self-monitoring $(0-18)$} & 11.13 & 2.58 & 10.81 & 2.27 & 8.52 & 2.63 & 7.25 & 2.40 \\
\hline & \multicolumn{2}{|l|}{$(n=63)$} & \multicolumn{2}{|c|}{$(n=80)$} & \multicolumn{2}{|c|}{$(n=81)$} & \multicolumn{2}{|c|}{$(n=84)$} \\
\hline
\end{tabular}

In our view, these profiles seem to make sense, as they describe and represent imaginable existing individuals. This provides face validity for our profile measure (Robertson, 1994). For profile 1, we might think of a rather nervous, hard-working individual who is trying and willing to keep the boss satisfied, possibly related to a preference for extrinsic rewards. In part, this profile seems to fit 'young starters' (for example, in research, sales or management), although after a while the profile may raise some 'career' trouble. Environmental changes may confuse the profile 1 individual, who then starts to face problems in finding intrinsic rewards and in developing independency and self-confidence. For profile 2, we might think of a far more (self-) versus satisfied person or colleague, not eager to excel in terms of performance, although liable in existing structures and long-term commitments, but with a rather serviceminded attitude. The stereotype bookkeeper seems to share characteristics with this profile. For profile 3, we might refer to the 'typical' successful individual: selfconfident, without too much sensitivity for environmental cues and requirements, being more self-directed. Together with ambition, success must be within reach, which is good for those in top positions (in management, sales or any other leader job). Profile 4, finally, represents mal-adapted persons, feeling not in control in their situation, probably quite anxious, and prone to failures and negative experiences. This profile seems therefore to be the least related to career and job successes.

In this paper, the effects of the personality traits and personality profiles on labor market outcomes will be assessed, in separate analyses, in terms of objective labor market entry success measures. For defining a 'successful' labor market entry, Van der Velden and Wieling (1994) argue that both chances for work and quality of the job should be considered. Several indicators could be

(footnote continued)

obtained), we conduct our labor market analyses with the personality profiles as obtained by the cluster analysis on the available 308 cases. used to reflect these success measures, such as finding a job soon after graduation, having tenure, occupying an academic job (a job for which a Master's degree is required), and earning high wages. We obtained labor market entry data from a survey sent to all Maastricht economics graduates a year and a half after graduation. In this survey, all kinds of information with respect to the search process, the labor market position and other activities are asked. Hence, the data are self-reports. This survey measurement is carried out on a regular basis by the Maastrich University's Research Centre for Education and the Labour Market (Dutch shortcut: ROA). Studies are published each year on the subsequent graduation cohorts of the University Maastricht (Ramaekers, 1996, 1997; Ramaekers \& Welters, 1998). For the purpose of our study, the 1994-1996 waves are used. These waves contain most of the economics graduates for whom personality data are available.

To test for the effects of personality features (i.e., profiles and traits) on labor market outcomes, the following four dependent variables are taken on board as measures of labor market entry performance: (a) finding a job within 3 months after graduation; (b) having a tenure position; (c) occupying a job for which an academic degree is required; and (d) gross monthly wages. Next to our independent variables, the personality measures introduced above, relevant covariates are considered for their effect on labor market entry performance. The following 10 covariates are included: (1) gender (dummy, with male coded 1); (2) age (years); (3) GPAs of the last 2 years of the study program (10point scale); (4) final thesis result (10-point scale); (5) managerial experience during education (dummy); (6) (relevant) working experience during education (dummy); (7) study field (marketing and organization, accounting and finance, or otherwise, indicated by dummies); (8) working in the profit sector (dummy); (9) working in a small or medium-sized company (dummy); and (10) having a leadership position (dummy). In terms of Fig. 1, covariates (3)-(6) relate to human capital variables (Arrow 2a-b), and (7)-(10) involve the individual domain preferences (Arrow 3a-b). 
Control variables (1) and (2) are standard in labor market research.

Logistic and normal linear regression analyses are conducted twice: once with the personality profiles and once with the personality traits. The analyses involve a three-step hierarchical estimation. In the first step, only the personality features and demographic covariates (i.e., age and gender) are included (Model 1). In the second step, the preferential study field variable is introduced into the model (Model 2); and in the third, step, the traditional human capital variables - study results, managerial experience and working experienceare taken on board (Model 3). In so doing, the second and third-step models analyze the direct effect of personality features, whilst controlling for human capital variables and individual domain preferences. In the wage regressions, a fourth-step model is tested so as to control for the job and organizational preferences of students (Model 4), which is of course not meaningful in the context of the other labor market outcomes.

\section{Results}

First of all, descriptives and plots for all variables were analyzed for outliers and normality. All interval variables show a near normal distribution. Descriptive data and Pearson's correlations are presented in Tables 3 and 4.

A large majority of the sample found a job within 3 months after graduation $(79 \%)$. Of all graduates in our sample, $63 \%$ has a tenured position at the date of the survey, whereas $49 \%$ occupies an 'academic' job. The gross monthly wages are 3835 Dutch guilders (now about $€ 1743$ ), on average. There are more males than females in this study (males 57\%), and the average age is about 26 years at the time of the labor market survey. Of all graduates, $48.5 \%$ have passed through the marketing and/or organization specialization, whereas $28.7 \%$ have specialized in accounting and/or finance. The remaining $22.8 \%$ have graduated in different specialization tracks. For the purpose of our study, it is statistically not interesting to split this group further into several smaller sub-groups. Study fields in this reference category are, for example, 'general' (i.e., non-business) economics or quantitative economics. During their study, $45 \%$ of the students have gained relevant working experience, and $59 \%$ have accumulated ditto managerial experience. Of all graduates, $91 \%$ work in the profit sector, and $77 \%$ in a large firm. Already a $21 \%$ of the graduates are promoted into a leadership position, a year and a half after graduation. Note that this percentage is based on self-reports. Finally, with respect to the correlations between covariates, at first sight, multicollinearity is not an issue.
Table 5 report the results of the logistic regression analyses with respect to the effects of personality profiles and separate traits on the first labor market indicatorthe odds of having a job within 3 months after graduation.

All models differ significantly from the base model in which only the constant is included. The large parameter value of the constant refers to the high probability of having a job within 3 months anyway. The third personality profile has a large (direct) effect on having a job within 3 months, after controlling for the influence of individual domain preferences and human capital variables. With respect to these control variables, the study fields show large positive effects. In Table 5 b, with the separate personality traits, only Models 2 and 3 differ significantly from the base model. The effect of personality traits is significant for the locus of control scale: externality produces negative effects, again after controlling for the impact of individual domain preferences and human capital variables. Overall, the personality profile effect is more profound than the influence of the separate personality characteristics.

In the next analysis, the chance of having tenure is explored. Table 6 present the results.

Now, none of the models differs significantly from the base model in which only a constant is included. However, in Table 6a, the third personality profile shows a positive effect on the odds of having tenure, even after controlling for the role of human capital variables and individual domain preferences. Additionally, we observe a moderately significant positive effect of GPAs. In Table 6b, a stable positive effect of type A behavior appears and a negative effect of locus of control externality. Overall, for this labor market indicator, the separate personality traits are more informative than the personality profiles.

The next indicator for success of labor market entry is occupying a job for which an academic degree is required. Table 7 report the results of these analyses.

Again, none of the models differs significantly from the base model. For this labor market indicator, a profound positive effect of the third personality profile is found again. In Model 3, after introducing the traditional human capital variables, a positive effect is observed for the final thesis result. In the analyses with separate personality traits, no effects for personality are found. However, this time more human capital variables appear relevant: the final thesis result and managerial experience reveal positive effects. Apparently, personality only has an effect on the odds of getting an academic job when it is seen in terms of integrated characteristics, not in terms of separate traits.

In the final analyses, the effects of personality profiles and traits on gross monthly wages are considered. Table 8 present the results. Note that the single graduate who is working on a $\mathrm{PhD}$ thesis is left out because of the 
Table 3

Descriptive statistics and Pearson's correlations for most variables in the sample

\begin{tabular}{|c|c|c|c|c|c|c|c|c|c|c|c|}
\hline \multirow[t]{2}{*}{ Variables } & \multirow[t]{2}{*}{ Mean } & \multirow[t]{2}{*}{$\mathrm{SD}$} & \multirow[t]{2}{*}{ JV } & \multicolumn{8}{|l|}{ Correlations } \\
\hline & & & & (1) & (2) & (3) & (4) & $(5 a)$ & $(6 a)$ & (7a) & $(8 a)$ \\
\hline Labor market entry indicators & & & & & & & - & - & - & - & - \\
\hline (1) Being unemployed less than 3 months & 0.790 & 0.410 & 168 & - & - & - & - & - & - & - & - \\
\hline (2) Having a tenured job & 0.630 & 0.480 & 157 & $0.172^{* *}$ & - & - & - & - & - & - & - \\
\hline (3) Having a job requiring an academic degree & 0.470 & 0.500 & 156 & $0.187^{* *}$ & 0.004 & - & - & - & - & - & - \\
\hline (4) Gross monthly wages (log) & 8.252 & 0.237 & 150 & $0.266^{* * *}$ & $0.334^{* * *}$ & $0.312^{* * *}$ & - & - & - & - & - \\
\hline \multicolumn{12}{|l|}{ Personality traits (score range) } \\
\hline (6a) Locus of control (0-23) & 10.561 & 3.717 & 171 & -0.077 & -0.124 & -0.103 & $-0.150^{*}$ & -0.085 & - & - & - \\
\hline (7a) Sensation seeking $(0-51)$ & 12.116 & 1.627 & 271 & 0.013 & 0.010 & 0.129 & $0.137^{*}$ & $0.287^{* * *}$ & $-0.362^{* * *}$ & - & - \\
\hline (8a) Self-monitoring $(0-18)$ & 9.216 & 3.050 & 171 & 0.024 & 0.031 & 0.3 & 0.083 & $0.300^{* *}$ & -0.122 & $0.287^{* * *}$ & - \\
\hline \multicolumn{12}{|l|}{ Covariates } \\
\hline Gender (male) & 0.580 & $0.500 *$ & 171 & $-0.136^{*}$ & -0.013 & 0.033 & -0.024 & $-0.145^{*}$ & -0.124 & $0.197 * * *$ & 0.042 \\
\hline Age & 25.860 & 1.260 & 171 & $-0.193^{* *}$ & -0.039 & -0.087 & 0.0870 & 0.012 & -0.066 & 0.095 & -0.080 \\
\hline Study field marketing and organization & 0.467 & 0.500 & 171 & 0.010 & -0.051 & 0.037 & -0.081 & 0.068 & -0.015 & 0.043 & 0.062 \\
\hline Study field accounting and finance & 0.274 & 0.447 & 171 & $0.202^{* * *}$ & 0.107 & 0.000 & -0.018 & -0.002 & $0.155^{* *}$ & -0.054 & -0.058 \\
\hline Study field otherwise (reference group) & 0.259 & 0.439 & 171 & $-0.228 * * *$ & -0.059 & -0.045 & 0.119 & -0.079 & $-0.150^{* *}$ & 0.007 & -0.011 \\
\hline Grade point average & 6.759 & 0.515 & 171 & $0.5151^{7}$ & $0.173^{* *}$ & 0.106 & 0.127 & 0.002 & $-0.147^{*}$ & 0.021 & 0.017 \\
\hline Final thesis result & 7.347 & 0.756 & 171 & 0.113 & 0.022 & $0.200^{* *}$ & 0.044 & 0.113 & -0.044 & $0.167^{* *}$ & 0.047 \\
\hline Working experience & 0.470 & 0.500 & 171 & -0.027 & 0.095 & -0.006 & 0.072 & 0.123 & -0.124 & 0.106 & 0.079 \\
\hline Managerial experience & 0.610 & 0.490 & 171 & -0.029 & 0.036 & $0.181^{* *}$ & 0.121 & $0.143^{*}$ & -0.124 & $0.260^{* * *}$ & $0.130^{*}$ \\
\hline Working in the profit sector & 0.900 & 0.310 & 160 & -0.086 & $0.224^{* * *}$ & -0.110 & $0.180^{* *}$ & 0.127 & 0.045 & 0.017 & 0.048 \\
\hline Working in a small or medium-sized firm & 0.220 & 0.410 & 160 & 0.022 & $-0.161^{* *}$ & -0.0424 & $-0.156^{*}$ & -0.045 & $0.163^{* *}$ & -0.118 & 0.070 \\
\hline \multirow[t]{2}{*}{ Having a leadership position } & 0.211 & 0.409 & 160 & $0.153^{*}$ & 0.103 & -0.031 & $0.145^{*}$ & $0.195^{* *}$ & -0.047 & 0.001 & 0.118 \\
\hline & & & & & & & $(5 b)$ & $(6 b)$ & $(7 b)$ & (8b) & \\
\hline (5b) Profile 1 & $21.6 \%$ & $=$ & 37 & -0.010 & -0.129 & -0.042 & 0.026 & & - & - & - \\
\hline (6b) Profile 2 & $25.2 \%$ & $=$ & 43 & -0.109 & -0.024 & -0.007 & -0.013 & $-0.305^{* * *}$ & & & \\
\hline (7b) Profile 3 & $26.3 \%$ & $=$ & 45 & $0.152^{* *}$ & $0.174^{* *}$ & $0.169^{* *}$ & $0.119^{* *}$ & $-0.314^{* * *}$ & $-0.346^{* * *}$ & - & - \\
\hline \multirow[t]{2}{*}{ (8b) Profile 4} & $26.9 \%$ & $=$ & 46 & -0.037 & -0.079 & -0.026 & $-0.221^{* * *}$ & $-0.319^{* * *}$ & $-0.352^{* * *}$ & $-0.363^{* * *}$ & - \\
\hline & & & 171 & & & & & & & & \\
\hline
\end{tabular}

Note: Mean scores and SDs for the separate personality traits in each profile are presented in Table 2 .

${ }^{*}$ Correlation significant at the 0.1 level.

${ }^{* *}$ Correlation significant at the 0.05 level.

${ }^{* * *}$ Correlation significant at the 0.01 level (two-sided). 


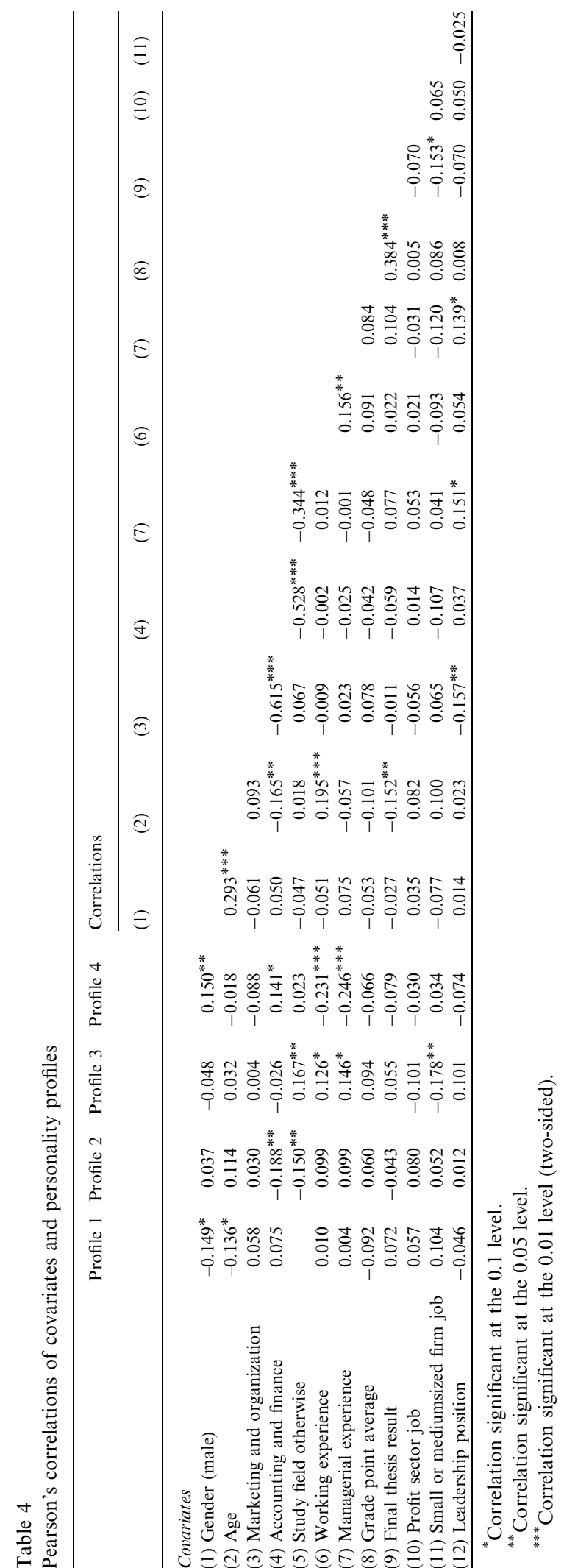

regulated low wages for PhD students in the Netherlands.

All Models 1-4 differ significantly from the base model. For the personality profiles, stable positive effects are found for both the first and third profile. For the second profile, the effect fades away after introducing our human capital variables in Model 3. Table 8b reveals that mainly type A behavior is associated with a stable positive effect. The significant effect of the locus of control trait disappears when traditional human capital variables are introduced. The effect of GPAs possibly accounts for this. In Model 4, additionally, academic job level and firm size affect wages. Here, type A behavior remains important. A high score for type A behavior is, in fact, what the first and third personality profile have in common.

Table 9 summarizes our findings.

The effects of personality, measured through combined profiles or separate traits, are clearly relevant for the explanation of labor market entry outcomes in our sample of Dutch graduates in economics. ${ }^{2}$ An important overall finding is that the effects of personality are stable, even after controlling for traditional human capital variables. Effects of traditional human capital variables are present as well, for each labor market indicator, which suggests that including both types of data is associated with value added.

With respect to the use of combined personality profiles vis-a-vis separate personality traits, the results indicate that different mixtures of characteristics produce different effects on different labor market outcomes. Not surprisingly, graduates with profile 4 (the unambitious, rather rigid, external person) are clearly the least successful. Labor market entrants with profile 3, who represent the ambitious, internal and flexible persons who are willing to take reasonable risks, are clearly the most successful in all labor market outcomes. This, again, is not surprising as this profile corresponds to the ideal-typical personality type that many employers would prefer, ceteris paribus. People with profile 1 also obtain higher entry wages, which is probably due to the ambitious nature of these graduates. Graduates with profile 2 also obtain higher wages, although the effect of their personality seems merely indirect, possibly through the effect of better

\footnotetext{
${ }^{2}$ For all labor market outcomes, an interaction effect of personality with gender has been considered as well. Only for a tenured position a significant interaction effect appears for type A behavior: type A behavior seems especially positive for women. This finding may be explained by the existence of a relative masculine working environment with ditto work values for graduated economists, in which especially women need to display type A behavior to stay competitive compared to men (see e.g., Judd \& Oswald, 1997; Schein, Mueller, \& Jacobson, 1989).
} 
Table 5

Logistic regression of the effects of personality on having a job within 3 months

\begin{tabular}{|c|c|c|c|c|c|c|}
\hline & \multicolumn{2}{|l|}{ Model 1} & \multicolumn{2}{|l|}{ Model 2} & \multicolumn{2}{|l|}{ Model 3} \\
\hline & $\mathrm{B}$ & S.E. & $\mathrm{B}$ & S.E. & $\mathrm{B}$ & S.E. \\
\hline \multicolumn{7}{|l|}{ (a) } \\
\hline Constant & $9.631^{* *}$ & 4.021 & $9.293^{* *}$ & 4.330 & 1.609 & 5.645 \\
\hline \multicolumn{7}{|l|}{ Personality profiles } \\
\hline Profile 1 & -0.120 & 0.553 & -0.168 & 0.581 & -0.052 & 0.606 \\
\hline Profile 2 & -0.227 & 0.508 & 0.221 & 0.546 & 0.310 & 0.575 \\
\hline Profile 3 & 0.934 & 0.605 & $1.337^{* *}$ & 0.656 & $1.483^{* *}$ & 0.696 \\
\hline \multicolumn{7}{|l|}{ Covariates } \\
\hline Age & $-0.314^{* *}$ & 0.157 & $-0.343^{* *}$ & 0.170 & $-0.302^{*}$ & 0.181 \\
\hline Gender (male) & -0.454 & 0.438 & -0.536 & 0.454 & -0.519 & 0.475 \\
\hline Marketing and organization & & & $1.013^{* *}$ & 0.463 & $1.096^{* *}$ & 0.480 \\
\hline Accounting and finance & & & $2.178^{* * *}$ & 0.677 & $2.325^{* * *}$ & 0.693 \\
\hline Grade point average & & & & & 0.594 & 0.443 \\
\hline Final thesis result & & & & & 0.379 & 0.311 \\
\hline Working experience & & & & & -0.228 & 0.464 \\
\hline Managerial experience & & & & & -0.219 & 0.444 \\
\hline \multicolumn{7}{|l|}{ Model statistics } \\
\hline Number of cases $(n)$ & & 168 & & 168 & & 168 \\
\hline Model chi-square & & 11.916 & & 24.542 & & 29.410 \\
\hline-2 Log likelihood & & 162.663 & & 150.037 & & 145.169 \\
\hline Df & & 5 & & 7 & & 11 \\
\hline$P$ & & 0.036 & & 0.001 & & 0.002 \\
\hline \multicolumn{7}{|l|}{ (b) } \\
\hline Constant & $10.078^{* *}$ & 3.975 & $8.759^{* *}$ & 4.324 & 1.811 & 5.750 \\
\hline \multicolumn{7}{|l|}{ Personality traits } \\
\hline Type A behavior & 0.216 & 0.216 & 0.189 & 0.223 & 0.226 & 0.232 \\
\hline Locus of control & -0.242 & 0.215 & $-0.432^{*}$ & 0.229 & $-0.415^{*}$ & 0.236 \\
\hline Sensation seeking & 0.005 & 0.239 & 0.019 & 0.248 & -0.010 & 0.258 \\
\hline Self-monitoring & -0.061 & 0.200 & -0.034 & 0.199 & -0.012 & 0.207 \\
\hline \multicolumn{7}{|l|}{ Covariates } \\
\hline Age & $-0.327^{* *}$ & 0.154 & $-0.307^{*}$ & 0.168 & -0.275 & 0.183 \\
\hline Gender (male) & -0.422 & 0.446 & -0.582 & 0.467 & -0.549 & 0.483 \\
\hline Marketing and organization & & & $0.963^{* *}$ & 0.458 & $1.028^{* *}$ & 0.473 \\
\hline Accounting and finance & & & $2.206^{* * *}$ & 0.669 & $2.295^{* * *}$ & 0.680 \\
\hline Grade point average & & & & & 0.565 & 0.460 \\
\hline Final thesis result & & & & & 0.346 & 0.312 \\
\hline Working experience & & & & & -0.185 & 0.463 \\
\hline Managerial experience & & & & & -0.276 & 0.443 \\
\hline \multicolumn{7}{|l|}{ Model statistics } \\
\hline Number of cases $(n)$ & & 168 & & 168 & & 168 \\
\hline Model chi-square & & 9.925 & & 23.210 & & 27.461 \\
\hline-2 Log likelihood & & 164.654 & & 151.369 & & 147.118 \\
\hline Df & & 6 & & 8 & & 12 \\
\hline$P$ & & 0.128 & & 0.003 & & 0.007 \\
\hline
\end{tabular}

*Significant at 0.10 .

** Significant at 0.05 .

*** Significant at 0.01 (two-sided).

GPAs, or a preference for working in a large firm. When using separate personality traits, rather consistent results appear. On the one hand, type A behavior and an internal locus of control do indeed pay off. On the other hand, sensation seeking and self-monitoring fail to produce any separate effect. For the academic jobs, 
Table 6

Logistic regression of the effects of personality on having tenure

\begin{tabular}{|c|c|c|c|c|c|c|}
\hline & \multicolumn{2}{|l|}{ Model 1} & \multicolumn{2}{|l|}{ Model 2} & \multicolumn{2}{|l|}{ Model 3} \\
\hline & $\mathrm{B}$ & S.E. & $\mathrm{B}$ & S.E. & $\mathrm{B}$ & S.E. \\
\hline \multicolumn{7}{|l|}{ (a) } \\
\hline Constant & 3.080 & 3.503 & 1.969 & 3.589 & -1.879 & 4.942 \\
\hline \multicolumn{7}{|l|}{ Personality profiles } \\
\hline Profile 1 & -0.233 & 0.480 & -0.197 & 0.487 & -0.169 & 0.507 \\
\hline Profile 2 & 0.405 & 0.470 & 0.658 & 0.496 & 0.560 & 0.517 \\
\hline Profile 3 & $0.958^{*}$ & 0.491 & $1.133^{* *}$ & 0.509 & $1.064^{* *}$ & 0.533 \\
\hline \multicolumn{7}{|l|}{ Covariates } \\
\hline Age & -0.109 & 0.138 & -0.085 & 0.140 & -0.095 & 0.151 \\
\hline Gender (male) & 0.000 & 0.366 & -0.072 & 0.372 & 0.025 & 0.386 \\
\hline Marketing and organization & & & 0.281 & 0.443 & 0.189 & 0.453 \\
\hline Accounting and finance & & & $0.915^{*}$ & 0.519 & 0.853 & 0.531 \\
\hline Grade point average & & & & & $0.671^{*}$ & 0.398 \\
\hline Final thesis result & & & & & -0.061 & 0.264 \\
\hline Working experience & & & & & 0.248 & 0.376 \\
\hline Managerial experience & & & & & -0.056 & 0.369 \\
\hline \multicolumn{7}{|l|}{ Model statistics } \\
\hline Number of cases $(n)$ & & 157 & & 157 & & 157 \\
\hline Model chi-square & & 7.152 & & 10.757 & & 14.915 \\
\hline-2 Log likelihood & & 199.664 & & 196.059 & & 191.901 \\
\hline Df & & 5 & & 7 & & 11 \\
\hline$P$ & & 0.210 & & 0.150 & & 0.186 \\
\hline \multicolumn{7}{|l|}{ (b) } \\
\hline Constant & 2.832 & 3.500 & 1.582 & 3.633 & -2.336 & 5.023 \\
\hline \multicolumn{7}{|l|}{ Personality traits } \\
\hline Type A behavior & $0.460^{* *}$ & 0.197 & $0.467^{* *}$ & 0.200 & $0.507^{* *}$ & 0.206 \\
\hline Locus of control & $-0.341^{*}$ & 0.197 & $-0.443^{* *}$ & 0.209 & $-0.379^{*}$ & 0.214 \\
\hline Sensation seeking & -0.208 & 0.206 & -0.205 & 0.207 & -0.213 & 0.220 \\
\hline Self-monitoring & -0.038 & 0.182 & -0.013 & 0.181 & -0.037 & 0.185 \\
\hline \multicolumn{7}{|l|}{ Covariates } \\
\hline Age & -0.094 & 0.137 & -0.056 & 0.141 & -0.077 & 0.153 \\
\hline Gender (male) & 0.123 & 0.376 & 0.007 & 0.385 & 0.136 & 0.396 \\
\hline Marketing and organization & & & 0.219 & 0.440 & 0.120 & 0.454 \\
\hline Accounting and finance & & & $0.868^{*}$ & 0.521 & 0.792 & 0.534 \\
\hline Grade point average & & & & & $0.788^{* *}$ & 0.397 \\
\hline Final thesis result & & & & & -0.138 & 0.270 \\
\hline Working experience & & & & & 0.277 & 0.374 \\
\hline Managerial experience & & & & & 0.058 & 0.374 \\
\hline \multicolumn{7}{|l|}{ Model statistics } \\
\hline Number of cases $(n)$ & & 157 & & 157 & & 157 \\
\hline Model chi-square & & 8.370 & & 11.730 & & 17.086 \\
\hline-2 Log likelihood & & 198.446 & & 195.086 & & 189.730 \\
\hline Df & & 6 & & 8 & & 12 \\
\hline$P$ & & 0.212 & & 0.164 & & 0.146 \\
\hline
\end{tabular}

*Significant at 0.10 .

${ }^{* *}$ Significant at 0.05 .

though, none of the separate traits seem of interest to employers, while the third personality profile, that combines characteristics of all four traits, is considerably valued. Apparently, for some labor market features, the conception of personality in terms of a combination of characteristics is more important than a conception in terms of separate traits. For the separate traits, the sensation seeking and self-monitoring concepts (con- 
Table 7

Logistic regression of the effects of personality on having an academic job

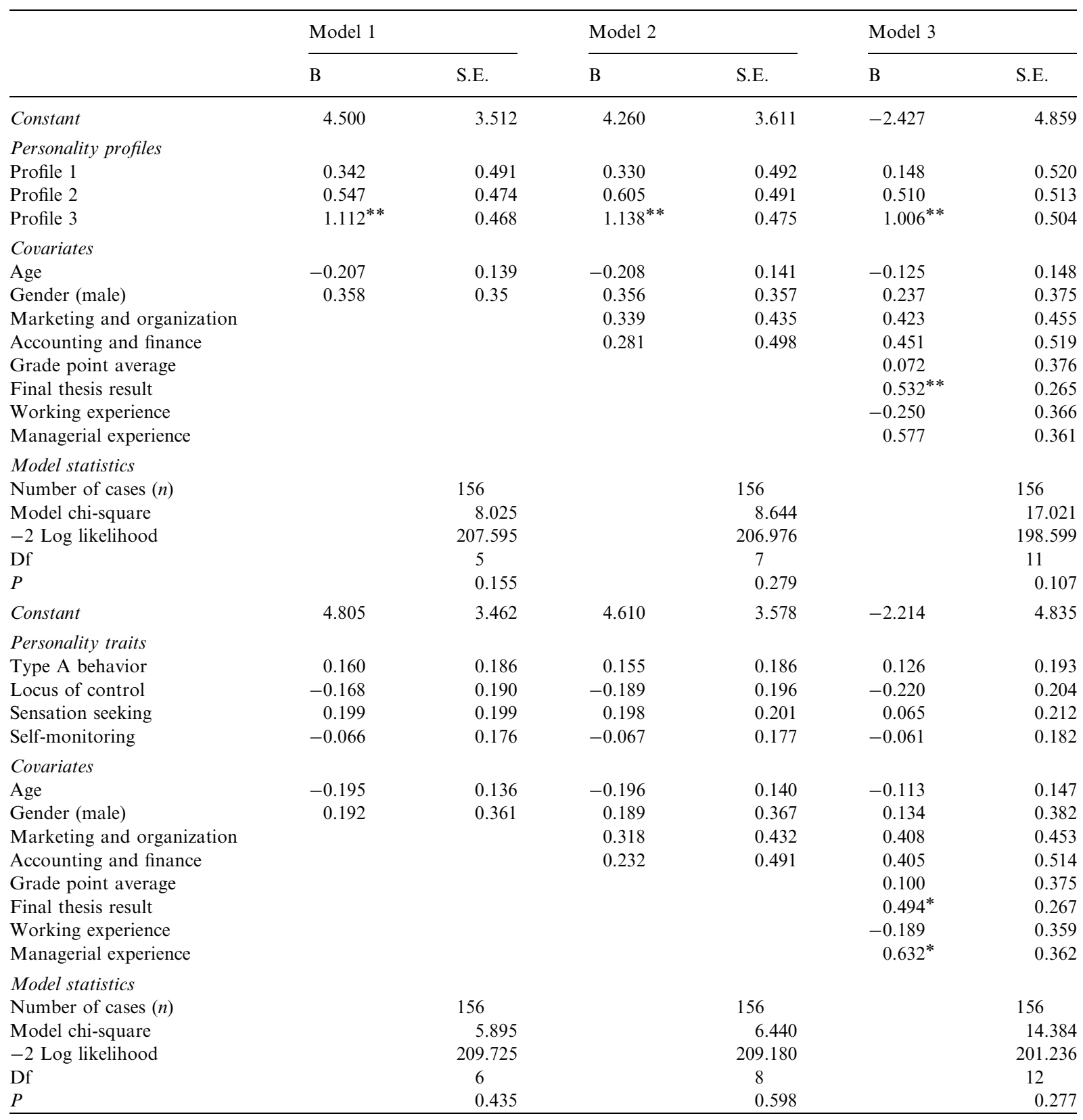

*Significant at 0.10 .

*** Significant at 0.05 .

trary to the locus of control and type A behavior features), though relevant for work-related issues after labor market entry, are not considered to be effective screening signals in the employee selection process of fresh university graduates in economics.

\section{Conclusion and appraisal}

In this study, the value added of personality characteristics has been explored in the context of explaining four labor market outcomes. A successful 
Table 8

Regression of the effects of personality on gross monthly wages

\begin{tabular}{|c|c|c|c|c|c|c|c|c|}
\hline & \multicolumn{2}{|l|}{ Model 1} & \multicolumn{2}{|l|}{ Model 2} & \multicolumn{2}{|l|}{ Model 3} & \multicolumn{2}{|l|}{ Model 4} \\
\hline & $\mathrm{B}$ & S.E. & $\mathrm{B}$ & S.E. & $\mathrm{B}$ & S.E. & $\mathrm{B}$ & S.E. \\
\hline \multicolumn{9}{|l|}{ (a) } \\
\hline Constant & $7.939^{* * *}$ & 0.362 & $7.970^{* * *}$ & 0.368 & $7.279^{* * *}$ & 0.509 & $7.122^{* * *}$ & 0.473 \\
\hline \multicolumn{9}{|l|}{ Personality profiles } \\
\hline Profile 1 & $0.097^{*}$ & 0.052 & $0.103^{*}$ & 0.052 & $0.104^{*}$ & 0.053 & $0.109^{* *}$ & 0.050 \\
\hline Profile 2 & $0.093^{*}$ & 0.050 & $0.090^{*}$ & 0.052 & 0.075 & 0.052 & 0.050 & 0.050 \\
\hline Profile 3 & $0.155^{* * *}$ & 0.049 & $0.154^{* * *}$ & 0.049 & $0.134^{* * *}$ & 0.050 & $0.087^{*}$ & 0.048 \\
\hline \multicolumn{9}{|l|}{ Covariates } \\
\hline Age & 0.009 & 0.014 & 0.0150 & 0.014 & 0.016 & 0.015 & $0.025^{*}$ & 0.014 \\
\hline Gender (male) & -0.013 & 0.037 & -0.015 & 0.037 & -0.016 & 0.038 & -0.039 & 0.036 \\
\hline Marketing and organization & & & $-0.087^{*}$ & 0.046 & $-0.098^{* *}$ & 0.046 & $-0.102^{* *}$ & 0.044 \\
\hline Accounting and finance & & & 00.050 & 0.050 & -0.053 & 0.052 & -0.073 & 0.050 \\
\hline Grade point average & & & & & $0.071^{*}$ & 0.039 & $0.067^{*}$ & 0.037 \\
\hline Final thesis result & & & & & 0.008 & 0.027 & -0.013 & 0.025 \\
\hline Working experience & & & & & 0.003 & 0.037 & -0.005 & 0.035 \\
\hline Managerial experience & & & & & 0.040 & 0.037 & 0.022 & 0.035 \\
\hline Profit sector job & & & & & & & $0.101^{*}$ & 0.060 \\
\hline Small/medium-sized firm job & & & & & & & $-0.105^{* *}$ & 0.043 \\
\hline Academic level required & & & & & & & $0.153^{* * *}$ & 0.034 \\
\hline Leadership position & & & & & & & 0.034 & 0.042 \\
\hline \multicolumn{9}{|l|}{ Model statistics } \\
\hline Number of cases $(n)$ & & 149 & & 149 & & 149 & & 147 \\
\hline Adjusted R-square & & 0.040 & & 0.052 & & 0.065 & & 0.202 \\
\hline$F$ & & 2.246 & & 2.153 & & 1.929 & & 3.466 \\
\hline$P$ & & 0.053 & & 0.042 & & 0.041 & & 0.000 \\
\hline \multicolumn{9}{|l|}{ (b) } \\
\hline Constant & $8.053 * * *$ & 0.350 & $8.084^{* * *}$ & 0.358 & $7.450 * * *$ & 0.487 & $7.335^{* * *}$ & 0.461 \\
\hline \multicolumn{9}{|l|}{ Personality traits } \\
\hline Type A behavior & $0.068^{* * *}$ & 0.020 & $0.068^{* * *}$ & 0.019 & $0.067^{* * *}$ & 0.020 & $0.056^{* * *}$ & 0.019 \\
\hline Locus of control & $-0.041^{* *}$ & 0.020 & $-0.039^{*}$ & 0.021 & -0.033 & 0.021 & -0.019 & 0.020 \\
\hline Sensation seeking & 0.004 & 0.022 & 0.003 & 0.022 & -0.000 & 0.022 & 0.001 & 0.021 \\
\hline Self-monitoring & -0.005 & 0.018 & -0.003 & 0.018 & -0.004 & 0.018 & 0.002 & 0.017 \\
\hline \multicolumn{9}{|l|}{ Covariates } \\
\hline Age & 0.008 & 0.014 & 0.009 & 0.014 & 0.013 & 0.014 & 0.021 & 0.014 \\
\hline Gender (male) & -0.023 & 0.038 & -0.025 & 0.038 & -0.022 & 0.038 & -0.044 & 0.037 \\
\hline Marketing and organization & & & $-0.081^{*}$ & 0.044 & $-0.092^{* *}$ & 0.045 & $-0.098^{* *}$ & 0.043 \\
\hline Accounting and finance & & & -0.045 & 0.050 & -0.049 & 0.050 & -0.067 & 0.048 \\
\hline Grade point average & & & & & $0.070^{*}$ & 0.038 & $0.063^{*}$ & 0.036 \\
\hline Final thesis result & & & & & 0.003 & 0.026 & -0.015 & 0.025 \\
\hline Working experience & & & & & 0.005 & 0.036 & -0.001 & 0.034 \\
\hline Managerial experience & & & & & 0.042 & 0.036 & 0.022 & 0.035 \\
\hline Profit sector job & & & & & & & 0.083 & 0.059 \\
\hline Small/medium-sized firm job & & & & & & & $-0.090^{* *}$ & 0.042 \\
\hline Academic level required & & & & & & & $0.146^{* * *}$ & 0.033 \\
\hline Leadership position & & & & & & & 0.012 & 0.042 \\
\hline \multicolumn{9}{|l|}{ Model statistics } \\
\hline Number of cases $(n)$ & & 149 & & 149 & & 149 & & 147 \\
\hline Adjusted $R$-square & & 0.095 & & 0.104 & & 0.188 & & 0.232 \\
\hline$F$ & & 3.584 & & 3.150 & & 2.648 & & 3.764 \\
\hline$P$ & & 0.002 & & 0.003 & & 0.003 & & 0.000 \\
\hline
\end{tabular}

Note: One case, representing an individual who is working on a dissertation, is excluded from the analyses.

*Significant at 0.10 .

${ }^{* * *}$ Significant at 0.05 .

**** Significant at 0.01 (two-sided). 
Table 9

Summary of significant results

\begin{tabular}{|c|c|c|c|c|c|c|c|c|c|c|c|c|c|}
\hline \multirow{4}{*}{$\begin{array}{l}\text { Predictors } \\
\\
\text { Personality }\end{array}$} & \multicolumn{13}{|c|}{ Labor market outcomes } \\
\hline & \multirow{2}{*}{\multicolumn{3}{|c|}{$\begin{array}{l}\text { Being unemployed } \\
\text { less than } 3 \text { months } \\
\text { Model }\end{array}$}} & \multicolumn{3}{|c|}{ Having tenure } & \multicolumn{3}{|c|}{$\begin{array}{l}\text { Occupying an } \\
\text { academic job }\end{array}$} & \multicolumn{4}{|c|}{ Gross monthly wages } \\
\hline & & & & \multicolumn{3}{|c|}{ Model } & \multicolumn{3}{|c|}{ Model } & \multicolumn{4}{|c|}{ Model } \\
\hline & 1 & 2 & 3 & 1 & 2 & 3 & 1 & 2 & 3 & 1 & 2 & 3 & 4 \\
\hline Profile 1 & & & & & & & & & & a & $\overline{\mathrm{a}}$ & $\mathrm{a}$ & a \\
\hline Profile 2 & & & & & & & & & & a & a & & \\
\hline Profile 3 & & a & a & a & a & a & a & a & a & a & a & a & a \\
\hline Type A behavior & & & & a & a & a & & & & a & a & a & a \\
\hline Locus of control & & $\mathrm{b}$ & $\mathrm{b}$ & $\mathrm{b}$ & $\mathrm{b}$ & $\mathrm{b}$ & & & & $\mathrm{b}$ & $\mathrm{b}$ & & \\
\hline Sensation seeking & & & & & & & & & & & & & \\
\hline Self-monitoring & & & & & & & & & & & & & \\
\hline Covariates & & & & & & & & & & & & & \\
\hline Study field & a & & & & & & & & & & $\mathrm{b}$ & $\mathrm{b}$ & $\mathrm{b}$ \\
\hline Grade point average & & a & & & & a & & & & & & & \\
\hline Final thesis result & & & & & & & & & a & & & & \\
\hline Managerial experience & & & & & & & & & a & & & & \\
\hline Profit sector job & & & & & & & & & & & & & a \\
\hline Small/medium-sized firm job & & & & & & & & & & & & & $\mathrm{b}$ \\
\hline Academic level required & & & & & & & & & & & & & a \\
\hline
\end{tabular}

${ }^{\text {a }}$ Effect of the independent variable is positive.

${ }^{\mathrm{b}}$ Effect of the independent variable is negative.

transition from education to work is important, because labor market entry affect careers later in life (Van der Linden \& Van der Velden, 1998). The results reported above underline the importance of personality characteristics for several labor market outcomes. This relatively new finding for labor market research is in line with current job selection practices, where personality characteristics already fight for prominence in job ads and assessment procedures. An important overall finding is the rather direct and solid effect of personality on all labor market outcomes. Our hypothesis, that personality has an effect on labor market outcomes next to traditional human capital variables (such as study results) and individual domain preferences (such as study field) can therefore be confirmed.

Finally, related to the shortcomings of the present study, we want to point to three examples of interesting avenues for further research. First, although we find a significant effect of personality features on labor market outcomes, the variables taken on board here appear not to be overly adequate to 'explain' the mechanisms underlying this relationship. That is, whether this effect is caused by the selection behavior of employers or by the unobserved choice and performance behavior of graduates, or by both, remains an interesting area for further research. Similarly, we focus on short-term labor market outcomes only. It would be interesting to find out whether these effects can still be traced when analyzing longer-term labor market performance, many years after entry. If personality features are indeed significantly related to labor market outcomes, one should be able to find long-run consequences, too.

Second, the findings for graduates in economics cannot simply be generalized to other graduation populations. The economics curriculum is considered to reflect a rather 'generic' program, similar to management or law studies, but opposed to more specific types of professional (academic) education. After all, there is no specific profession at which the economics study is tailored, as it merely prepares the graduates for a range of different functions in many different organizations for which different specific types of knowledge and skills may be important. These specific knowledge and skills cannot all be acquired within the educational program, and thus many are still to be learnt after entering into a job. This may explain the importance of personality characteristics for economics graduates, next to the specific human capital they already have acquired, since it is important for employers to assess the personality features and long-run potential of candidate employees, especially in this case where learning-on-the-job is so important. For more specific profession-targeting studies, such as medicine, the effects of personality characteristics might be much smaller, or may be quite different. In such professional education programs, the acquired knowledge and skills are highly standardized for each and every student. It is necessary to unravel the impact of these educational differences to develop a 
clear view on the effects of personality features on labor market outcomes for graduates of different types of study (specialization).

Third, and related to the second suggestion above, is the observation that we need far more theory development on the linkages between and among the personality profiles and traits on the one hand, and different labor market outcomes on the other hand. In the present study, forced by the lack of earlier labor market research in this area, we choose traits that have proven relevance in managerial and organizational contexts. However, in different jobs or organizations - that is, in different segments of the labor market-other profiles and traits might be more important to explain failure and success. A more systematic approach-linking personality types, job characteristics and labor market outcomes - seems a useful endeavor in light of the huge popularity of all kinds of 'soft' personality features in the day-to-day employee selection practices in many organizations. In other words, we need to develop a contingency theory of the impact of personality features on labor market and career success that helps to offer a solid rationale for the use of such screening devices. By so doing, we can hopefully move beyond the exploratory nature of the present study.

\section{Acknowledgements}

This research has been supported by the Netherlands Organization for Scientific Research (NWO). The authors like to thank the following persons for their helpful comments on earlier versions of the paper: the participants of the EDINEB-conference in 1999 in Bergen/Norway, the participants of the Human Capital workshop in 2000 in Maastricht/The Netherlands, Jim Allen, Andries de Grip, and the anonymous referees of this journal.

\section{References}

Appels, A. (1985). De Jenkins activity survey. Lisse: Swets \& Zeitlinger.

Barrick, M. R., \& Mount, M. K. (1991). The Big Five personality dimensions and job performance: A metaanalysis. Personnel Psychology, 44, 1-26.

Barrick, M. R., \& Mount, M. K. (1993). Autonomy as a moderator of the relationships between the Big Five personality dimensions and job performance. Journal of Applied Psychology, 78, 111-118.

Becker, G. S. (1964). Human capital. New York: NBER.

Blau, G. J. (1987). Locus of control as a potential moderator of the turnover process. Journal of Occupational Psychology, 60, 21-29.

Boone, C. (1992). Onderzoek naar het verband tussen de perceptie van controle van bedrijfsleiders en de strategie en de resultaten van ondernemingen in de meubelindustrie. Unpublished doctoral dissertation. Antwerpen: University of Antwerpen.

Boone, C., De Brabander, B., Gerits, P., \& Willemé, P. (1990). Relation of scores on Rotter's I-E scale to short-term and long-term control expectancies and fatalism. Psychological Reports, 66, 1107-1111.

Boone, C., De Brabander, B., \& Van Witteloostuijn, A. (1996). CEO locus of control and small firm performance: An integrative framework and empirical test. Journal of Management Studies, 33, 667-699.

Boone, C., De Brabander, B., \& Van Witteloostuijn, A. (1999). The impact of personality on behavior in five prisoner's dilemma games. Journal of Economic Psychology, 20, 343-377.

Borg, M. O., \& Shapiro, S. L. (1996). Personality type and student performance in principles of economics. Journal of Economic Education, 27, 3-25.

Boudreau, J. W., Boswell, W. R., \& Judge, T. A. (2001). Effects of personality on executive career success in the United States and Europe. Journal of Vocational Behavior, 58, 53-81.

Boyatzis, R. E., Cowen, S. S., \& Kolb, D. A., et al. (1995). Innovation in professional education: Steps on a journey from teaching to learning. The story of change and invention at the Weatherhead School of Management. San Francisco: JosseyBass Publishers.

Burke, R. J., \& Deszka, E. (1982). Preferred organizational climates of type A individuals. Journal of Vocational Behavior, 21, 50-59.

Caspi, A., \& Roberts, B. W. (2001). Personality development across the life course: The argument for change and continuity. Psychological Inquiry, 12, 49-66.

Cellini, H. R., \& Lorenz, J. R. (1983). Job club group training with unemployed offenders. Federal Probation, 46, 46-50.

De Brabander, B., Boone, C., \& Gerits, P. (1992). Locus of control and cerebral asymmetry. Perceptual and Motor Skills, 75, 131-143.

De Fruyt, F., \& Mervielde, I. (1999). RIASEC types and big five traits as predictors of employment status and nature of employment. Personnel Psychology, 52, 701-727.

Duncan, G. J., \& Dunifon, R. (1998). Soft skills and long-run labor market success. In S. W. Polachek, \& J. Robst (Eds.). Research in labor economics, Vol. 17 (pp. 123-149). London: JAI Press.

Feather, N. T., \& Volkmer, R. E. (1988). Preference for situations involving effort, time pressure, and feedback in relation to type A behavior locus of control and test anxiety. Journal of Personality and Social Psychology, 55, 266-271.

Feij, J. A., \& Van Zuilen, R. W. (1984). Handleiding bij de spanningsbehoeftelijst (SBL). Lisse: Swets \& Zeitlinger.

Filer, R. K. (1981). The influence of affective human capital on the wage equation. In R. Ehrenberg (Ed.). Research in labor economics, Vol. 4 (pp. 367-416). Greenwich, CT: JAI Press.

Franken, R. E. (1988). Sensation seeking decision making styles and preference for individual responsibility. Personality and Individual Differences, 9, 139-146.

Friedman, M., \& Rosenman, R. H. (1974). Type A behavior and your hart. New York: Knopf.

Gleick, J. (1999). Faster: The accelaration of just about everything. New York: Pantheon Books. 
Goldsmith, A. H., Veum, J. R., \& Darity, W. (1997). The impact of psychological and human capital on wages. Economic Inquiry, 35, 815-829.

Hogan, R., Hogan, J., \& Roberts, B. W. (1996). Personality measurement and employment decisions: Questions and answers. American Psychologist, 51, 469-477.

Judd, P. C., \& Oswald, P. A. (1997). Employment desirability: The interactive effects of gender-typed profile, stimulus sex, and gender-typed occupation. Sex Roles, 37, 467-476.

Kilduff, M., \& Day, D. V. (1994). Do chameleons get ahead?: The effects of self-monitoring on managerial careers. Academy of Management Journal, 37, 1047-1060.

Kilduff, M., \& Krackhardt, D. (1994). Bringing the individual back in: A structural analysis of the internal market for reputation in organizations. Academy of Management Journal, 37, 87-108.

Murnane, R. J., Willett, J. B., Braatz, M. J., \& Duhaldeborde, Y. (2001). Do different dimensions of male high school students' skills predict labor market success a decade later? Evidence from the NLSY. Economics of Education Review, 20, 311-320.

Nicholson, N. (1996). Towards a new agenda for work and personality: Traits self-identity 'strong' interactionism and change Guest editors' introduction. Applied Psychology: An International Review, 45(1), 1-28.

Nijhof, W. J. (1998). Qualifying for the future. In W. J. Nijhof, \& J. N. Streumer (Eds.), Key qualifications in work and education. Dordrecht: Kluwer Academic Publishers.

Pervin, L. A. (1990). Personality: Theory and research (5th ed.). London: John Wiley and Sons.

Ramaekers, G. W. M. (1996). WO-scanner economie 1995: Basismeting cohort '94ROA-R-1996/15. Maastricht: Research Centrum voor Onderwijs en Arbeidsmarkt.

Ramaekers, G. W. M. (1997). WO-monitor economie 1996: Basismeting cohort '95ROA-R-1997/4. Maasricht: Research Centrum voor Onderwijs en Arbeidsmarkt.

Ramaekers, G. W. M., \& Welters, R. A. M. H. M. (1998). Start van de loopbaan na de Universiteit Maastricht 1996-1997. ROA-R-1998/7. Maastricht: Research Centrum voor Onderwijs en Arbeidsmarkt.

Robbins, S. P. (1996). Organizational behavior: Concepts, controversies, applications (7th ed.). Englewood Cliffs, NY: Prentice Hall.

Robertson, I. T. (1994). Personality and personnel selection. In C. L. Cooper, \& D. M. Rousseau (Eds.), Trends in organizational behavior (pp. 84-93). London: John Wiley.

Rotter, J. B. (1966). Generalized expectancies for internal versus external control of reinforcement. Psychological Monographs, 80(1), 1-28.

Schein, V. E., Mueller, R., \& Jacobson, C. (1989). The relationship between sex role stereotypes and requisite management characteristics among college students. Sex Roles, 20, 103-110.

Schneider, B. (1987). The people make the place. Personnel Psychology, 40, 437-453.

Smith, M., \& George, D. (1994). Selection methods. In G. L. Cooper, \& I. T. Robertson (Eds.), Key reviews in managerial psychology: Concepts and research for practice. London: Wiley.

Snyder, M. (1974). Self-monitoring of expressive behavior. Journal of Personality and Social Psychology, 30, 526-537.

Snyder, M., \& Copeland, J. (1989). Self-monitoring processes in organizational settings. In R. A. Giacalone, \& Rosenfeld (Eds.), Impression management in the organization (pp. 7-19). Hillsdale, NY: Erlbaum.

Snyder, M., \& Gangestad, S. (1986). On the nature of selfmonitoring: Matters of assessment, matters of validity. Journal of Personality and Social Psychology, 51, 125-139.

Spector, P. E. (1982). Behavior in organizations as a function of employee's locus of control. Psychological Bulletin, 91, 482-497.

Spencer, L. M., \& Spencer, S. M. (1993). Competence at work: Models for superior performance. New York: John Wiley and Sons.

Tett, R. P., Jackson, D. N., \& Rothstein, M. (1991). Personality measures as predictors of job performance: A meta-analytic review. Personnel Psychology, 44, 703-742.

Thurow, L. C. (1975). Generating inequality. New York: Basic Books.

Timmers, W. (1997). Persoonlijkheid, leerstijl en studieresultaat. Los Contact, 17, 9-10.

Van den Berg, P. T. (1992). Persoonlijkheid en werkbeleving: De validiteit van persoonlijkheidsvragenlijsten, in het bijzonder die van een spanningsbehoeftelijst. Amsterdam: Centrale Huisdrukkerij VU.

Van der Linden, A. S. R., \& Van der Velden, R. K. W. (1998). The effects of unemployment and mismatches on future job match and earnings. In T. Lange (Ed.), Understanding the school-to-work transition: An international perspective (pp. 109-124). Commack, NY: Nova Science Publishers.

Van der Velden, R. K. W., \& Wieling, A. (1994). De arbeidsmarktkansen per opleiding. In H. Scholten, \& S. C. De (Eds.), Arbeidsmarkt en sociale zekerheid: Beleid en beweging (pp. 106-114).

Zuckerman, M. (1979a). Sensation seeking: Beyond the optimal level of arousal. Hillsdale, NY: Erlbaum.

Zuckerman, M. (1979b). Sensation seeking and risk taking. In Izard (Ed.), Emotions in personality and psychopathology (pp. 163-197). New York: Plenum Press.

Zuckerman, M. (1991). Psychobiology of personality. Cambridge, MA: Cambridge University Press. 